\title{
2
}

\section{THE RISE OF CLASSICAL BRAHMANISM}

\author{
Johannes Bronkhorst
}

Brahmans play a prominent role in Hinduism in most of its forms. They constitute a caste-class (varna) and claim descent from the seers who "saw" the ancient Vedic hymns. They officiated in Vedic times at the sacrifices that were (or aspired to be) an essential part of political life. Their vital role in all kinds of rituals continued beyond those days, well into the present.

From a Brahmanical point of view, the history of Brahmans and of the institutions for which they have been responsible is continuous. From their perspective, Brahmans were there from immemorial time to look after the ritual aspects of society, incorporating traditional knowledge and wisdom and advising rulers on the correct way to run society and their kingdoms. What is more, Brahmans considered themselves to be, and to have always been, at the top of the social hierarchy.

An inspection of the historical evidence shows that this vision of the past is not correct. Such an inspection brings up a far more complex picture, in which the rise of Brahmanism was a long and difficult process, with several ups and downs.

Our point of departure is the late Vedic period, the period during which texts were composed dealing with complex rituals - we'll call them Vedic sacrifices. These Vedic sacrifices were carried out by sacrificial priests, the Brahmans, for the benefit of rich and powerful patrons. This happened in the northwestern regions of the Indian subcontinent, including regions that now lie in Pakistan. This sacrificial and priestly tradition was closely associated with the political order in those regions, just as the sacrificial and priestly traditions of ancient Egypt and of ancient Mesopotamia were part of the political systems in those parts of the world.

The sacrificial and priestly traditions of ancient Egypt and ancient Mesopotamia did not survive the collapse of those political systems. One might have expected the same in South Asia, but this is not what happened. The following pages will consider how the Vedic political systems came to an end and how the responses of those primarily affected, the Brahmans, led to something altogether new.

A succession of political events effectively put an end to the Vedic sacrificial tradition. The first one we know about in some detail is the invasion of the Indian subcontinent (327-325 BCE) by Alexander of Macedonia, often called Alexander the Great. He and his army did not penetrate deeply into the subcontinent; in fact, their movements were confined to what is now Afghanistan and Pakistan and never reached present-day India. But the regions they did visit, especially in what is now Pakistan, had an influential population of Brahmans, and we learn 
from the Alexander historians that conflicts between them and Alexander arose on various occasions. Indeed, it appears that Alexander and his army slaughtered large numbers of Brahmans. It seems safe to assume that the political changes that resulted from Alexander's invasion undermined the Vedic sacrificial tradition to a considerable extent.

This was only the beginning. The regions of the Indian subcontinent that Alexander had conquered became, a few years after his death, part of the newly created Maurya Empire. This empire had its capital and cultural centre in the eastern part of the Ganges valley, in the city-Pâtaliputra - that was primarily capital of the region called Magadha. Magadha and its surroundings ("Greater Magadha") had been and continued to be the seat of a culture altogether different from the culture to which the Vedic sacrificial tradition belonged. Among the features that distinguished the culture of Greater Magadha, the belief in rebirth and karmic retribution is prominent. It is this belief, along with the desire to escape from rebirth and karmic retribution, that was responsible for the appearance of a number of religious movements - among these Buddhism and Jainism - that taught methods to bring about such an escape. Vedic sacrifices played no role in this part of the subcontinent, and Brahmans did not here receive the respect they expected and received in the Brahmanical heartland.

The Maurya Empire was-to the extent this was possible in an age where long-distance communication was slow and arduous-highly centralized. It appears that it did not keep local rulers in charge of their regions but rather replaced them with administrators sent from the capital. As a result, Vedic sacrifices lost their political and financial support. To make matters worse, one of the emperors - the famous Aśoka — made it known that animal sacrifices were no longer tolerated. Vedic sacrifices thus lost the support without which they could not be carried out. And the Brahmans, who embodied this sacrificial tradition, lost the main justification for their special place in society.

The collapse of the Maurya Empire (around 185 BCE) did not bring relief to Brahmans either, at least not to many of them. The northwestern regions which, until Alexander's invasion and perhaps beyond, had been a centre of Brahmanical culture (perhaps the most important one), underwent once again violent invasions, by Indo-Greeks and Scythians in particular. The Brahmans in those regions who had somehow survived the preceding two centuries while maintaining a separate identity experienced these invasions as so destructiveboth physically and culturally - that they (or at least a number of them) believed the end of the world was near and gave expression to that belief in a text from that period that has survived, the Yugapurāna.

Brahmans in certain other parts of the now-defunct Maurya Empire were luckier. The ruler of one of its successor kingdoms, the Śunga King Pusyamitra, is known to have performed a Vedic sacrifice (the aśvamedha "Horse Sacrifice", probably twice) and supported Brahmanical culture. And this was only the beginning. Over time, a reinvented form of Brahmanism succeeded in gaining the upper hand well beyond its original area, spreading all over the subcontinent and even into Southeast Asia. To understand how this was possible, it is necessary to see what modifications Brahmanism had undergone.

Brahmanical culture had already begun to change before the arrival of sympathetic rulers, that is, during the earlier, difficult centuries. That is to say that, no doubt under the pressure of unfavourable circumstances, Brahmanism had reinvented itself. The demand for expensive Vedic sacrifices had diminished, but rather than disappearing from the historical scene with them, Brahmans found themselves different roles in society. They did not, of course, reject their connection with those sacrifices, but this link became more and more hypothetical. With reduced support from and interaction with the outer world, Brahmanism entered into a period of interiorization, which expressed itself in various ways. 


\section{Johannes Bronkhorst}

Most obvious, perhaps, was the shift of emphasis to smaller rites that individuals could perform in their homes. This is the period during which the Gṛhyasutras, manuals for household ceremonies, were composed.

Ritual purity had always been a requirement for participation in a sacrifice. The Brahmans now made this into a central concern of their way of life, both within and outside sacrificial contexts. Newly composed texts, the Dharmasūtras, regulate all details of their lives, from birth to death (and even the periods preceding birth and following death). Purity implied minimal interaction with non-Brahmans, who were considered less pure. In fact, using a categorization that may have been invented earlier, Brahmans now strictly distinguished between others with whom ritual interaction was possible, the so-called Kșatriyas and Vaiśyas, and those with whom this had to be avoided, the Śüdras. Brahmans, Kșatriyas, and Vaiśyas jointly came to be called 'twice-born', unlike the Súdras.

The emphasis on purity was behind an idealization of the Brahman that became very important in literature and had interesting effects in the real world. The ideal Brahman does not interact with society at all. He lives in the forest and survives on what he finds there, essentially roots and fruits. He is often depicted as living in a hermitage (Sanskrit: äsrama), which he has presumably created himself, independently of society. He maintains the sacred fire that he has brought with him, recites Vedic texts, and is in the possession of supernatural powers.

In this idealized form, perfect Brahmans may not have been many in number, or they may not have existed at all. However, the aśrama that figures in literature corresponds to what is called agrahāra in inscriptions. An agrahāra is a royal donation of land or of a village to one or more Brahmans, along with the obligation of the inhabitants of that land or village to pass on their earnings to those Brahmans. Unlike the agrahāra, the áśramas described in literature are never presented as donations. This difference is easily explained: as a whole, áśramas occur in literature composed by Brahmans, agrahäras in inscriptions composed by or on behalf of rulers. The Brahmans' non-interaction with society would be compromised by the acceptance of gifts, so they conveniently overlooked that their äśramas had, more often than not, been donated (Bronkhorst 2016).

The emphasis on purity also manifests itself in the requirement of pure descent. In classical Brahmanism, there is essentially only one way to become a Brahman, namely by being born from parents who are both Brahmans. The story of Matanga told in the Mahäbhärata illustrates this. He is brought up as a Brahman but discovers one day that he really is an outcaste (candâala), because his mother had committed adultery with one. Austerities do not help him to gain Brahmanical status.

A further key requirement for being a Brahman was and remained, at least in theory, knowledge of the Veda. Every Brahman is supposed to know his Veda (of which there came to be four) or a portion thereof. Preserving the Vedic texts became a central concern that was all the more demanding since Vedic texts are ideally only preserved orally. A whole literature arose dealing with the phonetic peculiarities of each Veda. Along with it, treatises on phonetics in general and on the grammar of Sanskrit came into being.

This preoccupation with the Veda and its language underwent a significant development, probably after the collapse of the Maurya Empire. Brahmanism now claimed that both-the Veda and its language - are eternal, that is, beginningless. This claim was apparently based on the more general, but often implicit, assumption that the whole world is eternal; that is, that it has no history in any meaningful sense. The claim that the Veda is eternal became the basis for its interpretation, carried out by the specialists of Mīmāṃsā, who took this claim very literally. They observed that the Veda, since it has no beginning, has no author either, considering that an author stands at the beginning of the work he produces. For the same reason, it cannot 
refer to historical events, for the Veda was already infinitely old when those presumed events occurred. Being without an author, it is not possible to find the meaning of a Vedic passage as intended by its author; there is no such meaning. The Veda became in this way pure language, whose interpretation required sophisticated efforts so as to avoid falling in the trap of treating it like other texts, which we read (or listen to) in order to find out the intentions of their authors or to learn about things that happened in the past. The Mīmāmsāa interpreters had to avoid these pitfalls by interpreting many Vedic statements metaphorically. In the end, they accepted that only injunctions must be taken literally.

The claim that the world, the Veda, and its language are eternal is closely related to the conservative tendency of Brahmanism. Really new things cannot arise, and if they do, they are ignored to the extent possible. An example is writing. This was introduced late in most of the Indian subcontinent (Falk 2018). Brahmanism avoided mentioning it, even when it used it, pretending for a long time to continue a purely oral tradition (Bronkhorst 2011b).

A few more words must be said about the ideal Brahman as he is depicted in literature. He preferably lives in his hermitage, avoids contact with the world, recites the Veda, and is, because of all that, extraordinarily powerful. This is a recurring theme and may have played a crucial role in the almost miraculous growth and spread of Brahmanical influence during the centuries following their recovery. This image of sometimes irritable but nonetheless awe-inspiring and fearsome Brahmanical sages is omnipresent in such literary productions as the great Sanskrit epics: the Mahābhärata and the Rāmāyana. Unlike certain other forms of literature produced during the period — such as the Grihyasūtras and Dharmasūtras mentioned earlier, which were primarily for internal use - the epics and other such texts addressed a far wider audience. Indeed, it seems likely that the public recitation of these narrative texts contributed in no small degree to the idea of Brahmans as wise, holy, and extremely powerful. This, in its turn, encouraged rulers to invite Brahmans to their kingdoms under favourable conditions. We have seen that this often took the form of offering them agrahäras.

But Brahmans had also developed other skills that made their presence attractive to rulers. Presumably during this same period of transition, they had started producing books dealing with governance. The most important text of this genre that has survived is the Arthaśāstra. Its received version was completed late (perhaps third century CE; Olivelle 2013) but stands at the end of a long tradition. The pragmatic, even Machiavellian, nature of this text has struck modern commentators and reminds us that Brahmanical political advisors were in for business, not for defending morality (except, of course, the sacrosanct position of Brahmans in society).

The internal changes within Brahmanism described previously did not take place in a political vacuum; this we have seen. Indeed, changing political circumstances appear to have given them their initial impetus. Nor did they take place in a cultural vacuum. Our knowledge of those cultural circumstances is limited, but the confrontation and interaction with the culture of Greater Magadha stands out.

Perhaps the most striking feature of the culture of Greater Magadha, as observed previously, was the belief in rebirth and karmic retribution, a belief unknown to Vedic culture. This belief underlay a variety of religious movements that originated in Greater Magadha-among them Buddhism, Jainism, and Âjīikikism — whose shared goal was to put an end to the potentially endless cycle of rebirths determined by one's actions. Jainism represents the perhaps most typical response to the challenge: Its path to liberation from rebirth culminates in the candidate's physical and mental immobilisation. Forms of asceticism in which all forms of activity, or certain forms of activity (such as breathing or thinking), are reduced to the extent possible became a prominent feature of Hinduism in many of its manifestations. 


\section{Johannes Bronkhorst}

The emphasis on absence of activity, on immobility, left place for another belief, the belief that the core of one's being, one's real self, is by its nature inactive. Some considered the realisation that one's self is not involved in the actions carried out by body and mind sufficient to put an end to karmic retribution. This concept of an inactive self came to play an extremely important role in Indian thought, either in combination with immobility asceticism or without it.

The Vedic tradition was not acquainted with the belief in rebirth and karmic retribution until it underwent the influence of the culture of Greater Magadha. And even then, not all Brahmans welcomed the new belief. The most orthodox representatives of the Vedic tradition (most notably the followers of Mīmāṃsā) resisted and refused to accept it until the middle of the first millennium CE or perhaps even later. Other branches of Brahmanism, however, yielded more readily to the new belief, which they initially tried to incorporate into more traditional ways of Vedic thinking.

Those Brahmans who accepted the belief in rebirth and karmic retribution (they may have been the majority) were now confronted with two idealized lifestyles. We already met the ideal Brahman who does not interact with society, lives in a hermitage in the forest, and survives on what he finds there. This way of life had nothing to do with rebirth and karmic retribution. Those, on the other hand, who seriously strove to put an end to rebirth and karmic retribution opted for a different lifestyle altogether. Like the ideal Brahman depicted previously, they too left society, but not in order to withdraw to the forest. They rather survived by begging (as did the Buddhists, the Jainas, and other religious mendicants from Greater Magadha), which means that they continued to stay in contact with society. And unlike the idealized Brahman depicted previously, they did not spend their life in the pursuit of purity, and they did not maintain a sacred fire and so on. Their prime concern was not ritual purity but liberation from rebirth. As a means of reaching that goal, they engaged in the search for their real self.

How did the Brahmanical tradition choose between these two lifestyles? It didn't. It accepted both as legitimate ways of living one's life. In fact, it proposed four possible ways of life: (1) as a lifelong student of the Veda (brahmacārin), (2) as a wandering religious mendicant (parivräja), (3) as a forest-dweller (vänaprastha), or (4) as a householder (grhastha). This is the order in which these four ways are presented in what is perhaps the earliest surviving Dharmasutra, the Apastambadharmasūtra, which also uses this terminology. This order is not a temporal sequence. The Apastambadharmasūtra, as do other Dharmasūtras, presents a simultaneous choice out of four, not four stages of life. Options (2) (parivrāja) and (3) (vānaprastha) stand respectively for the seeker of liberation and for the ideal Brahman who totally withdraws from society. (Interestingly, the Apastambadharmasūtra distinguishes between two kinds of forest-dweller: (3a) the ascetic who aims at suppressing activities and ends his life through a fast to death, a way of life that clearly betrays the influence of the culture of Greater Magadha, and (3b) the ascetic who maintains his fire and continues performing his rites, aiming at supernatural powers.) Option (2) is clearly a non-Vedic way of life, the one borrowed from the culture of Greater Magadha (the $\bar{A}$ pastambadharmasūtra admits that this way of life is "opposed to the scriptures" [2.9.21.15-16]).

This choice of four possible ways of life became over time a sequence of four stages of life: (1) religious student (brahmacārin), (2) householder (grhastha), (3) forest-dweller (vānaprastha), (4) wandering religious mendicant (parivräja; later the term samnyāsin, 'renouncer', came into use). This sequence of four stages (confusingly also called āśrama, but not meaning 'hermitage' this time) became part of Hinduism, at least in theory (Bronkhorst 1993).

The spiritual practice of Yoga is related to the ascetic ways of life considered but is often treated separately in Brahmanical texts. The term and the practices it designates make their appearance in the Mahäbhārata and other contemporary Brahmanical texts. The term does not occur in this sense in non-Brahmanical texts from that period or before. It is used in 
Brahmanical texts to designate practices whose historical link with Greater Magadha is beyond doubt: practices in which mental or physical inaction, or inaction of both, take a central place. No such practices feature in earlier Vedic texts, nor does the word 'Yoga' occur there in this sense. It would indeed appear that this term is the most important Brahmanical contribution to Yoga (Bronkhorst 2011a).

The culture of Greater Magadha believed in rebirth and karmic retribution, that is, in the regular return of individual living beings. It similarly believed in the regular return of the world as a whole. That is to say, the world goes through time-cycles. We find the notion of immensely long periods, often called kalpas, in the early writings of Buddhism and Jainism and even in the scarce information we possess about $\bar{A}$ jīikism. This cyclical view of time was accompanied by a vision of the universe in which Mount Meru is situated at the centre, being surrounded by a number of continents. Nothing of the kind is found in Vedic literature, and there are strong reasons to believe that this complex of ideas belonged to Greater Magadha before it found its way into Brahmanical literature, first perhaps in the later portions of the Mahābhārata (GonzálezReimann 2002; Satinsky 2015).

Perhaps the first reference to cyclical time in surviving Brahmanical literature occurs in the Yugapurāna, a text mentioned earlier. It was composed by Brahmans under duress, who feared that the Brahmanical order of society was being destroyed by a succession of calamities, most prominently invasions by various groups of barbarians. Interestingly, these Brahmans thought that the world was about to come to an end, and they formulated this fear in terms of cyclical time: The present world period was coming to an end, but a new period would follow the total destruction of the world sometime soon. The most remarkable aspect of this testimony is that Brahmans who borrowed the notion of cyclical time from outside the Vedic tradition adjusted it to the desperate situation in which they found themselves, meanwhile making tremendous reductions to the lengths of the recurring periods. (The text has not forgotten that very long time cycles exist, because its concluding verse states that a hundred times a hundred thousand years (?) constitutes a kalpa and that a kalpa amounts to a thousand yugas; Mitchiner 2002: 48-49).

Traces of the belief in recurring cycles of short duration survive in a few other Brahmanical texts: the Mānavadharmaśāstra, some early Purānas, and the Mahābhārata. But soon Brahmanism, too, started thinking in terms of time cycles of immense duration. The classical picture that we find in the more recent Purānas gives precise lengths to these durations: a total duration (caturyuga) of 4,320,000 (human) years is divided into four yugas that succeed each other and whose duration is 1,728,000; 1,296,000; 864,000; and 432,000 years, respectively (Rocher 1986: 124). In other words, the acceptance of periods of immense lengths that had been part of the culture of Greater Magadha ended up becoming part of Brahmanical culture. This was not without its advantages, even for orthodox Brahmanical thinkers. For example, it allowed legal scholars to relegate rules of behaviour that they found objectionable to a previous world age and thus make them inapplicable to contemporary times (Olivelle 2017: 36f.).

There was, however, a problem. The notion of cyclical time is at first sight in contradiction with the idea of a world that never changes, a world in which the Veda was handed down from teacher to pupil from beginningless time. Brahmanical thinkers were aware of this apparent contradiction and proposed ways in which the eternal Veda could bridge the gap between succeeding world periods. Few, with the notable exception of certain orthodox Vedic interpreters (Mīmāmsakas), held on to the belief that the world had always been as it is today. Detailed descriptions of world periods and their divisions, their characteristics, and their durations are a central feature of the Purānas, texts that on account of their number and size constitute an important part of traditional Brahmanical literature. 


\section{Johannes Bronkhorst}

Classical Brahmanism is known for its different schools of philosophy. The most well known of these schools nowadays is no doubt Advaita Vedānta. It is important to remember that this is probably the most recent of the classical schools of Brahmanical philosophy. Neither Advaita Vedānta nor any other school of Vedānta is mentioned in Indian philosophical literature until roughly the middle of the first millennium CE. At that moment, other schools of philosophy had been in existence for centuries.

Virtually without exception, all classical Brahmanical schools of philosophy share one feature: the concept of a soul, or self, that is inactive. This feature is common to the ontology of Vaiśeșika and of Vedānta in most of its forms but is most prominently present in the philosophy of Sāmkhya. This philosophy divides all there is into two separate categories: the soul and everything that can act. The former is often called purușa in the texts of this school; it is pure consciousness, not affected by any activity, including mental activity. The other category is often called prakrti: 'Nature' or pradhāna, and it covers everything that acts, including mental activity.

This notion of an inactive soul or self suggests, once again, that the culture of Greater Magadha influenced the basics of Brahmanical philosophy. This does not mean that the different philosophies as we have them were borrowings from Greater Magadha; clearly they were not. However, there is a further reason to think that the Sāṃkya philosophy, more than, say, Vaiśeșika and Vedānta, remained close to a predecessor that once existed in that nonBrahmanical part of India. This is the circumstance that Sāmkhya is almost invariably associated with the name of Kapila, the primordial sage who supposedly promulgated this philosophy for the first time. Kapila appears in the early literature as a demon, an inhabitant of hell, and an opponent of the Vedic tradition.

Brahmanism did not only undergo the cultural influence of its surroundings, it also exerted influence. Brahmanical influence on Indian culture in general came to be extremely important. We have seen that Brahmanism created a literature on Dharma that initially confined itself largely to regulating the details of the Brahmans' life. This is still their primary focus in the early Dharmasūtras, but as time went on, texts on Dharma dedicated ever more space to the rules by which others must live. Political guidance for rulers, for example, gets more attention over time, and the rules of Dharma become ever more rules for society at large. Here, too, the concern with purity is central, and purity of descent receives much attention. Mixture of caste-classes through intermarriage (varnasamkara) is a certain way to guarantee a lower position in society to the offspring (Brinkhaus 1978).

These restrictions on behaviour came to exert an amazing influence on Indian society at large. This is confirmed quite independently by genetic research. A recent study of the genomes of a large number of individuals in India comes to the conclusion "that the practice of endogamy was established almost simultaneously, possibly by decree of the rulers, in upper-caste populations of all geographical regions, about 70 generations before present, probably during the reign (319-550 CE) of the ... Gupta rulers" (Basu et al. 2016). Also, an earlier study has found evidence for a shift to endogamy at different moments for speakers of Indo-European languages (on average 72 generations) and those of Dravidian languages (108 generations) (Moorjani et al. 2013). The authors of this study translate these numbers of generations into 1900 and 3000 years before the present, respectively. It is virtually impossible to determine the exact average length of a generation, yet it seems safe to conclude that a shift to endogamy took place during the first half of the first millennium CE, at least in northern India, and it is permitted to assume that the growing influence of Brahmanism played a role in this shift.

This chapter is to a large extent based on work published in my two books Greater Magadha (Brill, Leiden 2007; reprint: Motilal Banarsidass, Delhi 2013) and How the Brahmins Won (Brill, Leiden 2016), which contain detailed further references. 


\section{References}

Basu, Analabha, Neeta Sarkar-Roy and Partha P. Majumder (2016) "Genomic Reconstruction of the History of Extant Populations of India Reveals Five Distinct Ancestral Components and a Complex Structure." Proceedings of the National Academy of Sciences (PNAS) 113 (6): 1594-1599.

Brinkhaus, Horst (1978) Die altindischen Mischkastensysteme. Alt- und Neu-Indische Studien, 19. Wiesbaden: Franz Steiner.

Bronkhorst, Johannes (1993) The Two Sources of India Asceticism. Bern: Peter Lang. Reprint: New Delhi: Motilal Banarsidass, 1998.

Bronkhorst, Johannes (2011a) “The Brāhmaṇical Contribution to Yoga." International Journal of Hindu Studies, 15 (3): 318-322.

Bronkhorst, Johannes (2011b) "Illiteracy As Cultural Marker." Travaux de Symposium International 'Le livre. La Roumanie. L'Europe'. Troisième édition-20 à 24 Septembre 2010. Tomes III: La troisième section-Etudes Euro- et Afro-Asiatiques, 44-56. Bucarest: Bibliothèque de Bucarest.

Bronkhorst, Johannes (2016) “Āśŕramas, Agrahāras, and Monasteries.” In Ivan Andrijanić and Sven Sellmer (eds.), On the Growth and Composition of the Sanskrit Epics and Purānas, 137-160. Zagreb: Croation Academy of Sciences and Arts.

Falk, Harry (2018) “The Creation and Spread of Scripts in Ancient India." In Anne Kolb (ed.), Literacy in Ancient Everyday Life, 43-66. Berlin: De Gruyter.

González-Reimann, Luis (2002) The Mahābhārata and the Yugas: India's Great Epic Poem and the Hindu System of World Ages. New York: Peter Lang.

Mitchiner, John E. (2002) The Yuga Purāna. Critically ed., with an English translation and a detailed introduction. 2nd revised ed. Kolkata: Royal Asiatic Society of Bengal.

Moorjani, Priya, Kumarasamy Thangaraj, Nick Patterson, Mark Lipson, Po-Ru Loh, Peryasamy Govindaraj, Bonnie Berger, David Reich and Lalji Singh (2013) "Genetic Evidence for Recent Population Mixture in India." The American Journal of Human Genetics, 93 (3): 422-438.

Olivelle, Patrick (2013) King, Governance, and Law in Ancient India: Kautilya's Arthaśástra, a New Annotated Translation. Oxford: Oxford University Press.

Olivelle, Patrick (2017) A Dharma Reader: Classical Indian Law. New York: Columbia University Press.

Rocher, Ludo (1986) The Purānas. A History of Indian Literature, II/3. Wiesbaden: Otto Harrassowitz.

Satinsky, Ruth (2015) "What Can the Lifespans of Rșabha, Bharata, Śreyāmsa, and Ara Tell Us About the History of the Concept of Mount Meru?" International Journal of Jaina Studies, 11 (1): 1-24 (Online). 